\title{
O POLIMORFISMO DO ABUSO DE PODER NO PROCESSO ELEITORAL: O MITO DE PROTEU
}

\author{
EDUARDO FORTUNATO BIM
}

1. Introdução; 2. O Poder e o Direito; 3. O abuso de poder no direito privado e no público; 4. $O$ abuso de poder no processo eleitoral; 4.1 . Fundamentos da coibição; 4.2. Princípios que norteiam a repressão ao abuso de poder nas eleições; 4.2.1. O princípio da potencialidade; 4.2.1.1. Da tentativa do abuso; 4.2.2. O princípio da impessoalidade; 4.3. Espécies de abuso de poder no processo eleitoral; 4.3.1. Abuso de poder econômico; 4.3.2. Abuso de poder de autoridade ou político-administrativo; 4.3.3. Abuso de poder nos meios de comunicação social; 5. O mito de Proteu; 6 . $O$ polimorfismo do abuso de poder no direito eleitoral e o mito de Proteu; 6.1. Outros casos de abuso de poder no processo eleitoral; 7. Conclusão; 8. Referência bibliográficas.

\section{Introdução}

A regularidade e a lisura dos pleitos eleitorais de um País indicam o grau de desenvolvimento de sua Democracia, porque esta é legitimada pela soberania popular, consolidada por meio do exercício da livre vontade contida no voto.

A problemática do abuso dos detentores do Poder não tema novo. Suas raízes perderam-se no curso da história, porque o abuso do direito é tema tão antigo quanto o próprio Direito. $\mathrm{O}$ abuso de poder (ou de direito) é vício que tem potencialidade para macular os resultados das urnas, conspurcando a legitimidade democrática. Atinge a liberdade de voto e o direito à igualdade de condições dos concorrentes aos cargos eletivos. Sua repressão deve ser uma constante na mente dos operadores do direito, principalmente daqueles do direito eleitoral.

O abuso de poder no direito eleitoral é tema pouco explorado pela doutrina pátria, ocasionando entendimentos desatentos para a verdadeira problemática desta 
prática deletéria aos regimes democráticos. Não existe mais, sendo raras as exceções, aquela deturpação da legitimidade das eleições baseada no mapismo, na compra de votos, na utilização de dinheiro público para a montagem de comícios, bem como o transporte e/ou alimentação de eleitores, pagamento de horas extras a servidores públicos para ajudar a campanha dos candidatos da situação, sumiço de urnas, comparecimento às sessões eleitorais de pessoas já falecidas etc.

Hoje, há meios mais sutis' e eficazes de comprometer a higidez de um pleito.

O que pretendemos com esse estudo é definir o abuso de poder em função dos fins que orientam nosso ordenamento jurídico. Fazendo uma remodelagem constitucional (filtragem constitucional) ${ }^{2}$ na classificação da Lei de Inelegibilidades (LC 64/90), chegaremos à essência do abuso de poder na seara eleitoral e concluiremos que ele tem o dom do personagem mitológico Proteu: o polimorfismo.

\section{O Poder e o Direito}

O Poder é um fenômeno que deve ser analisado sob enfoque multidisciplinar. Costuma-se apontar o poder político como o único existente, mas não se deve ignorar todas as demais formas de poder que se "entrelaçam no comércio social e desempenham um papel protagônico, seja na Polícia, seja no Direito, embora não se refiram, diretamente, à direção da sociedade. Tal é o caso do poder econômico, tantas vezes desafiador e desequilibrador do próprio Estado; tal é o caso, ainda do poder de imprensa, do poder militar, do poder dos sindicatos ou dos grupos de pressão, entre outras dezenas de exemplos de poder institucionalizado não-politico.". ${ }^{3}$ Como bem salientou Diogo Figueiredo Moreira Neto: "é preciso não perder de vista que o poder estatal não exclui o poder grupal de outras instituições, nem, muito menos, o poder individual que é o fenômeno básico e originante dos demais." 4

Idêntico o pensamento de Fávila Ribeiro que, ao tratar sobre a repressão ao abuso de poder no processo eleitoral, afirmou: "É o poder, por suas injunções

1 Normalmente, para o eleitor, o abuso atua de forma subliminar, já que "alguns usos do poder dependem de estar ele oculto, de não ser evidente a submissão dos que capitulam a ele" (GALBRAITH, J. Kenneth, Anatomia do Poder, $3^{a}$ ed.. São Paulo: Pioneira. 1989, p. 3). Transpondo isso para a mídia é que se reconhece a existência da chamada propaganda invisivel (SOARES, Murilo C., "Televisão e Democracia", in MATOS, Heloiza e outros, Mídia, Eleiçōes de Democracia, São Paulo: Scritta, 1994, p. 122-123).

2 "A noção de filtragem constitucional toma como ponto de partida a noção de preeminência normativa da Constituição. partindo da concepção de Pacto Fundante como ordem normativa superior e vinculante, expressa a idéia de que toda a ordem jurídica deve ser lida à luz da Carta Fundamental e passada pelo seu crivo, de modo a eliminar as normas que não se conformem com ela" (SCHIER, Paulo Ricardo, Filtragem Constitucional - Construindo uma nova dogmática jurídica, Porto Alegre: Sérgio Antônio Fabris Editor, 1999, p. 145-146).

3 MOREIRA NETO, Diogo de Figueiredo, Teoria do Poder, São Paulo: Revista dos Tribunais, 1992, p. 18, grifos no originail.

4 Teoria do Poder. p. 18. 
compulsivas, que deve ser refreado. As pressões ostensivas promanavam outrora do poder político, em seus esgalhamentos administrativos, mas hoje se exprimem também pelas dominações privadas, razão a que sejam calafetados todos os flancos para obstar as nocivas investidas de qualquer tipo de poder, e não somente do poder público, pois todos compõem a realidade existencial da sociedade contemporânea, com reservas de nocividades subjacentes a demandar cautelas e rigorosas sanções." 5

Assim, liberdade e autoridade não podem ser vistas, sob a óptica do poder, como antíteses. Na verdade, ambas são exteriorizações do Poder que, no Estado democrático de direito, é delimitado pela Constituição. "Em suma, numa sociedade politicamente organizada, o poder do Estado não 'antagoniza' nem 'enfrenta' o poder dos grupos secundários nem o dos indivíduos. Cobertos pelas liberdades, direitos e garantias constitucionalmente assegurados, se não que se coordenam, pois todos os poderes estão partilhados, com seus âmbitos de ação demarcados, de sorte que os conflitos de interesses sempre poderão ser compostos a partir das regras de competência." 6

O Direito sempre preocupou-se com o Poder, aliás, uma das razões de sua existência é discipliná-lo. ${ }^{7}$ No início, a produção fundamental da ordem jurídica demanda uma atividade construtiva suprema, a ser cumprida pelo poder Constituinte, que deve trazer um lastro de legitimidade sem a qual não é válida. ${ }^{8}$

Desde então, o poder estatal, que antes se apresentava de forma una e ilimitada (desde que legítimo), passa a submeter-se ao sistema de distribuição de competências, com latitudes demarcadas, em conformidade com a estrutura organizacional adotada pela Constituição. Mas não somente o poder estatal tem sua limitação estabelecida pela Constituição, o não-político, seja ou não intitucionalizado, também encontra limites na Carta Maior, embora seja menos controlado que o político.

O documento fundamental da partilha de poderes é, como já dissemos, a Constituição política; nela devem estar explicitados claramente os lindes do poder do Estado, do poder de imprensa, do poder religioso, econômico, sindical etc.

No entanto, o que distingue o poder Estatal dos outros poderes é a sua capacidade de coerção. Embora com a sua criação os demais poderes não sejam suprimidos, estes não podem - ao contrário do estatal - exercer a coerção máxima sobre os que habitam em seu território. Por isso, Max Weber, ao conceituar o Estado, o definiu como sendo aquele que detém o monopólio legítimo da força.

5 RIBEIRO, Fávila, Abuso de Poder no Direito Eleitoral, $3^{2}$ ed., Rio de Janeiro: Forense, p. 23. 6 MOREIRA NETO. Diogo de Figueiredo, Teoria do Poder, p. 21.

7 Por isso a advertência de Celso Bastos: "Se perguntarmo-nos qual é o objeto fundamental com que se defronta uma Constituição vamos encontrar uma só resposta: a regulação jurídica do poder" (BASTOS, Celso, Comentários à Constituiçāo do Brasil, Sāo Paulo: Saraiva, 1988, vol. I, p. 132. grifamos).

8 José Eduardo Faria (Poder e Legitimidade, São Paulo: Perspectiva, 1978, p. 81) assevera que “a autoridade não pode fundamentar-se no direito positivo. porque é justamente esse quem precisa de autoridade para ser efidaz." 
Em suma, a Constituição regula e limita a utilização do poder, sendo que utilizá-lo em desconformidade ao que foi por ela permitido representa violação ao principio da supremacia constitucional.

Agora, veremos o abuso de poder do direito privado e no público para diferenciá-los do praticado em matéria eleitoral.

\section{O abuso de poder no direito privado e no público}

Preliminarmente, é mister salientar que quem tem direito tem poder. Por isso, neste trabalho, usaremos indistintamente as expressões abuso de poder e abuso de direito.

No campo do direito privado também são comuns os abusos no exercício de um direito. Foi aqui que a doutrina desenvolveu e aperfeiçoou o seu conceito.

Em vários casos, a aplicação fria e extremada da lei permite ao detentor de um direito qualquer exercitá-lo para finalidades não previstas no ordenamento, indo contra a função social que deve reger todo o direito. Não há direitos absolutos! Cicero teve essa intuição quando disse: summum jus summa injuria.

Sobre a questão da inexistência dos direitos absolutos, Washington de Barros Monteiro nos esclarece que: "A idéia do absoluto de que outrora impregnavam os direitos, se tornou obsoleta... Os tempos mudaram e com eles o direito. Condena-se presentemente o abuso do direito; como asseveram Marty et Raynaud, a pessoa que pretendessem se apegar à tese dos direitos absolutos, veria repelida pelos tribunais sua pretensão." 9

Caracterizar a natureza jurídica do abuso de direito é tema complexo. Há várias correntes que abordaram a matéria e o consenso - se é que ele existe no Direito — nunca foi alcançado.

Alguns negam a existência da figura do abuso porque diante dela já não se estaria em face de um direito, mas sim de um não-direito, de uma falta dele. Para outros, o abuso se manifestaria na intenção de prejudicar (teoria subjetiva). Outra corrente, coloca o critério identificador na ausência de interesse legítimo, quando seu exercício conflita com a finalidade social para a qual foi conferido (teoria objetiva).

Finalmente, alguns acreditam que o elemento discriminador estaria no exercício anormal ou irregular de um direito. "Se alguém prejudica a outrem, no exercício do seu direito, fica adstrito a reparar o dano, se anormal ou não-regular esse exercício. É a mesma teoria da responsabilidade civil fundada na culpa". ${ }^{10}$

Uma coisa porém é certa: “O problema do abuso de direito não deve ter sua solução dentro das normas sobre responsabilidade civil, mas sim dentro daquelas

9 MONTEIRO, Washington de Bartos, Curso de Direito Civil, 32* ed., São Paulo: Saraiva, 1994, vol. I, p. 282-283.

10 MONTEIRO, Washington de Barros, op. cit., p. 283. 
outras que exprimem os princípios gerais do direito." $\mathrm{O}$ Código Civil alemão (BGB), em seu $\S 226$, assim preceitua: " $O$ exercício de um direito é permitido, quando não possa ter outro fim que não o de causar prejuizo a outrem."

Embora a discussão desta questão não seja pertinente aos estreitos lindes deste trabalho, nós endossamos a opinião de Lúcio Flávio de Vasconcellos Naves, para quem a teoria do abuso de direito funda-se, exclusivamente, "na já consagrada relatividade de todos os direitos." 12

Esta teoria, que é tão antiga quanto o homem, veio a lume na consciência jurídica apenas no início do século XX. Henri de Page fala-nos sobre esta origem "Sob este nome, a teoria não existe senão depois do início do século $\mathrm{XX}$, e provocou, desde seu surgimento, vivas resistências. $\mathrm{Na}$ realidade, ela é tão velha quanto o mundo, e se apóia em razões a tal ponto evidentes que de fato não se compreende como foi possivel combatê-la." 13

O surgimento desta teoria esbarrou no individualismo preponderante pós-revolução francesa, para a qual qualquer idéia que ameaçasse o direito de propriedade era vista com reservas. Mas a realidade estava lá, para quem quisesse vê-la. Desde o direito romano se aplicam as regras da contenção do abuso de direito; nem em Roma a propriedade foi tão absoluta como apregoam os manuais de direito civil e romano.

$O$ direito público também conhece a teoria do abuso de direito. Foi desenvolvida pela doutrina francesa e, posteriormente, pela italiana. No Brasil, segundo a clássica lição de Hely Lopes Meirelles, ${ }^{14} \mathrm{o}$ abuso de poder é encarado sob dois prismas: $o$ excesso e desvio de poder.

O excesso de poder ocorreria quando o agente público, na prática de seus atos funcionais, ultrapasasse sua competência, ou seja, fosse além do permitido pela norma que lhe outorga poder para determinado ato. É vício extrínseco ao ato.

Já no desvio de poder há, por parte do agente público, um ato extrinsecamente perfeito, isto é, no limite da competência atribuída à autoridade; porém, na sua finalidade, no seu conteúdo, este é viciado, fere o princípio da moralidade administrativa, beneficia alguém em detrimento da coletividade, do interesse público. É vício intrínseco ao ato.

\section{Abuso de poder no processo eleitoral}

Um dos grandes problemas enfrentados na luta pela realização da verdadeira democracia no Brasil diz respeito à legitimidade dos nossos pleitos. Na história política brasileira não houve um só pleito em que não houvesse uma ameaça à plena

11 Roberto Goldschmidt apud NAVES, Lúcio Flávio de Vasconcellos, Abuso no Exercício do Direito, Rio de Janeiro: Forense, 1999, p. 42.

12 NAVES, Lúcio Flávio de Vasconcellos, op. cit., p. 23.

13 Apud NAVES, Lúcio Flávio de Vasconcellos, op. cit., p. 51.

14 Direito Administrativo Brasileiro, 26* ed., São Paulo: Malheiros, 2001, p. 104-106. 
concretização da democracia. O modo mais comum de se afetar a lisura e legitimidade do processo eleitoral vem na forma do abuso de poder.

O combate ao abuso de poder no processo eleitoral não pode ser confundido com o do direito privado ou público. ${ }^{15}$ Ao combatê-lo, deve o intérprete e aplicador do Direito ater-se à legitimidade e isonomia de oportunidades nas eleições; requisitos mínimos para uma verdadeira democracia.

$\mathrm{O}$ abuso de poder - é bom que se diga logo - é caracterizado como sendo um complexo de atos que desvirtuam a vontade do eleitor, violando o princípio da igualdade entre os concorrentes do processo eleitoral e o da liberdade de voto, que norteiam o Estado democrático de direito.

É para evitar a existência das chamadas democracias de fachada que se reprime o abuso de poder no processo eleitoral. Democracias de fachada são, no dizer do Prof. Samuel Finer, "um sistema em que as instituições, processos e salvaguardas liberal-democráticos estão estabelecidos na lei, mas são na prática manipulados e violados por uma oligarquia histórica, com o fito de permanecer no poder." 16

Fávila Ribeiro, tratando do abuso de poder econômico, bem caracteriza a conspurcação da Democracia representativa porque "todos os que se elevam ao poder, por um método que não derive limpidamente da vontade do povo, pode ser tudo, somente não poderá apresentar-se com a qualificação representativa, por se contrapor ao critério consagrado de legitimidade, correspondendo à forma venalizada da aquisição de determinados ofícios na organização feudal". ${ }^{17}$

\subsection{Fundamentos da coibição}

A repressão ao abuso de poder tem duplo fundamento: um principiológico implícito e outro "legal" explícito.

Os princípios por ele maculados estão relacionados diretamente com o republicano e o democrático. Isso porque "os princípios fundamentais do Direito Eleitoral político são, também, princípios constitucionais, desde que não existem princípios de Direito Eleitoral que não sejam, também políticos-constitucionais, que refletem direta ou indiretamente os princípios axiológicos fundamentais e os princípios constitucionais instrumentais." 18

15 "Para o Direito Eleitoral, a problemática do abuso de poder não pode ficar nos confinamentos públicos ou privados, tendo que transpor essas linhas em busca de apoios abrangentes que penetram a fundo nas circunstâncias concretas da realidade contemporânea, para que o regime democrático participativo tenha uma escorreita base de sustentação, expungindo de vicios que possam obstar ou macular a caráter genuíno da participação do povo nos processos eletivos e deliberativos diretos: plebiscito e referendo" (RIBEIRO, Fávila, Abuso de Poder no Direito Eleitoral, p. 21 ).

16 Apud RIBEIRO, Fávila, op. cit. p. 86-87.

17 RIBEIRO, Fávila, op. cit., p. 66.

18 BARACHO, José Alfredo de Oliveira, "A Teuria Geral do Direito Eleitoral e seus Reflexos no Direito Eleitoral Brasileiro", Informativo Eleitoral 10/24. 
Um regime republicano e democrático não prescinde da lisura e regularidade de seus pleitos, porque somente assim se resguardará a legitimidade popular e a igualdade de votos entre os concorrentes do processo eleitoral.

A igualdade é o signo fundamental tanto da democracia ${ }^{19}$ como da república. ${ }^{20}$

$O$ regime republicano é diretamente afetado pelo abuso na medida em que se pressupõe, para a sua existência, a isonomia de seus integrantes (princípio do tratamento equânime aos candidatos). Essa igualdade jurídica deve-se traduzir, no processo eleitoral, na igual oportunidade de acesso aos cargos eletivos entre os candidatos, e na igual oportunidade de influir na formação da vontade popular, em suma, na isonômica oportunidade de participação no processo eleitoral. Os que detêm o Poder não podem abusar dele para tirar ou dificultar o acesso dos menos favorecidos aos cargos eletivos. Nesse sentido, convém destacarmos dois preceitos salutares insculpidos na Constituição Portuguesa de 1976, in verbis: "Todos os cidadãos têm o direito de acesso, em condições de igualdade e liberdade, aos cargos públicos" (art. 50.1) e "As campanhas eleitorais regem-se pelos seguintes princípios: (...) b) Igualdade de oportunidades e de tratamento das diversas candidaturas" (art. 116. 3, b). ${ }^{21}$

Canotilho deixa isso claro quando ressalta que a "igualdade de oportunidades na concorrência eleitoral... foi um dos primeiros domínios onde se começou a tentar dar operatividade prática ao princípio da igualdade de oportunidades". ${ }^{22}$

Antonio Carlos Mendes, apoiado no jurista português Migual Galvão Telles, leciona que a repressão ao abuso de poder, assim como na seara econômica, ${ }^{23}$ objetiva "substituir o exercício incondicionado da liberdade de competição por um exercício

19 SILVA. José Afonso da, Curso de Direito Constitucional Positivo, $13^{\text {a }}$ ed., São Paulo: Malheiros. p. 206; CANOTILHO, J. J. Gomes, MOREIRA, Vital, Fundamentos da Constituição, Coimbra: Coimbra Editora, 1991, p. 80; SOUSA, Daniel Coelho de, Interpretação e Democracia, $2^{a}$ ed.. São Paulo: Revista dos Tribunais, 1979, p. 147; SOUZA, José Pedro Galvão de, Iniciação à Teoria do Estado, 2a ed., São Paulo: Revista dos Tribunais, 1976, p. 66: TOCQUEVILE, Alex, $O$ que é Democracia?, 2ª ed., Petrópolis: Vozes, 1996, p. 104.

20 ATALIBA, Geraldo, República e Constituiçāo, $2^{2}$ ed., São Paulo: Malheiros, 1998, p. 158 e 160; CARRAZZA. Roque A., Curso de Direito Constitucional Tributário, $15^{a}$ ed., Sāo Paulo: Malheiros. 2000, p. 45; ALVIM NETO. José Manoel Arruda, "A Liminar na Açâo Cautelar e a Suspensão da Exigibilidade do Crédito Tributário", in ALVIM, Teresa Arruda (coord.). Repertório de Jurisprudência e doutrina sobre Processo Tributário. São Paulo: Revista dos Tribunais, 1994, p. 30-31; ROCHA, Cármen Lúcia Antunes, "Democracia, Constituição e Administração", RTDP $26 / 64$.

21 O Min. Carlos Velloso já se pronunciou a respeito: “(...) O fato apontado a meu sentir, é caracterizador da influência do poder econômico, não sendo relevante indagar se houve, ou não, uma vontade determinada de produzir propaganda eleitoral. O que importa indagar é que a propaganda irregular existiu e porque existiu viciou a vontade de algum ou de alguns eleitores, em detrimento do principio de igualdade entre os candidatos" (RJTSE 6/1/351, grifamos. No mesmo sentido votou no REsp 8.857/AC, Ac. 11.241/AC. RJSTE 2/2/259 e ss.).

22 CANOTILHO, J. J. Gomes, Direito Constitucional, 6ª ed., Coimbra: Almedina, 1996, p. 451.

23 BRUNA, Sérgio Varella, $O$ Poder Econômico e a Conceituação do abuso em seu Exercício, São Paulo: Revista dos Tribunais, 1997, p. 62. 101 e 102. 
limitado através de normas que visem impor e assegurar 'regras do jogo' destinadas a garantir a 'genuidade' da concorrência — ou a salvá-la." 24

É que um dos princípios em que se assenta o Estado democrático é o da livre concorrência pelo poder, ${ }^{25}$ obviamente em condições de igualdade.

Só por isso percebe-se o quão perniciosa é a prática do abuso de poder na seara eleitoral para a Democracia. Esta, além de ter como um dos signos fundamentais a igualdade, tem seu principal sustentáculo no exercício do poder pelo povo $(\mathrm{CF}$, art. $1^{\circ}$, parágrafo único), o que é instrumentalizado pelo sufrágio popular ${ }^{26}$ Portanto, para a própria sobrevivência do regime democrático, é imperioso que o exercício do sufrágio popular transcorra dentro da lei e da ordem e de forma honesta, escorreita e tranqüila.

Como disse Paulo Lucas Verdú “há democracia porque há eleições livres e há eleições livres porque há democracia". ${ }^{27}$ É a consagração de uma das pilastras da Democracia, a liberdade, mais especificamente, a liberdade de voto, que deve ser combinada com a igualdade dos candidatos, partidos e soberania popular. ${ }^{28}$ Por isso, Taliba Nogueira define o estado democrático como sendo aquele que se apóia sobre a confiança do povo e "organiza os podêres públicos de modo que a vontade popular, livre, paire acima de qualquer outra." 29

Ressalte-se que a liberdade de voto é garantida, entre outras coisas, por seu sigilo, mas não se resume somente a isto; embora o sigilo seja uma condição necessária, não é suficiente; na verdade, a liberdade de voto transcende à essa questão. Não podemos crer, como faz Paolo Barile ${ }^{30}$ em uma leitura precipitada da Declaração Universal dos Direitos do Homem (art. 21, 3), que somente o sigilo garante a liberdade de voto. Essa solução é demasiadamente simples, restritiva e ignora que o abuso de poder, principalmente no processo eleitoral, atua de forma subliminar (Galbraith), pouca ou nenhuma diferença fazendo que a votação seja ou não secreta. $O$ voto pode ser secreto e estar contaminado (e por isso mesmo não ser livre) bem antes do dia da votação, ou seja, a vontade popular pode ser conspurcada antes do ato de votar. Insistimos: para que o voto seja livre é necessário garantir,

24 "Apontamentos sobre o Abuso de Poder Econômico em Matéria Eleitoral", Cadernos de Direito Constitucional e Leitoral 3/24.

25 ALCUBILlA, Enrique Arnaldo, El Régimen Electoral de España, Madri: Centro de Estudios Políticos y Constitucionales, 1999, p. 15.

26 BARRACHO, José Alfredo de Oliveira, "A Teoria Geral do Direito Eleitoral e seus Reflexos no Direito Eleitoral Brasileiro", Informativo Eleitoral 10/13.

27 Curso de Derecho Político, Madrid: Tecnos, 1976, vol. III, apud ALCUBILLA, Enrique ARNNALDO, op. cit., p. 17, tradução livre.

28 Declaração Universal dos Direitos do Homem, em seu art. 21, 3 prevê que "A vontade do povo é o fundamento da autoridade dos poderes públicos e deve exprimir-se através de eleições honestas a realizar periodicamente por sufrágio universal e igual, com voto secreto ou segundo processo que salvaguarde a liberdade de voto."

29 Lições de Teoria Geral do Estado, São Paulo: Revista dos Tribunais, 1969, p. 105, grafia original.

30 Corso di Diritto Constituzionale, $2^{\mathrm{a}}$ ed., Padova: CEDAM, 1964, p. 88. 
além do sigilo, a isonomia dos participantes do pleito e evitar abusos culturais, econômicos, políticos etc. A Democracia pressupõe a livre concorrência pelo poder, de acesso aos cargos eletivos, ou seja, eleições livres.

Como muito bem observou Lauro Barreto, a lisura do processo eleitoral não pode ficar limitada à exatidão da conferência numérica entre o resultado final e o voto das urnas, deve-se ir além, ou seja, deve-se transcender a essa operação matemática e garantir ao cidadão "no processo individual e personalíssimo de reflexão que o deveria levar à escolha de seu candidato, a possibilidade de uma opção completamente liberta e descompromissada de qualquer pressão que possa influenciá-lo ou coagi-lo de tal forma que seu voto, longe de ser fruto de uma decisão pessoal, assuma feições de simples imposição de tal pressionamento. É indispensável, ainda, que aos candidatos, a todos os candidatos, sejam oferecidos, em perfeita igualdade de condições, os meios de levar ao conhecimento do eleitorado as suas mensagens e propostas." 31

É exatamente neste ponto que ressaltamos o caráter pétreo do combate ao abuso de poder no processo eleitoral. Porque mesmo não havendo expressa previsão constitucional nesse sentido, qualquer tentativa de macular sua legitimidade e limpidez atenta contra a liberdade de voto e a isonomia dos concorrentes ao pleito. Esses dois princípios são resguardados pela cláusula do art. $60, \S 4^{\circ}$, inc. IV da $\mathrm{CF} / 88$, de maneira que qualquer condescendência com o abuso de poder viola esses princípios fundamentais do cidadão e, ipso facto, a cláusula limitativa do poder constituinte reformador.

Já no campo explícito, a ofensa também vem diretamente da Constituição, cujo artigo $14\left(\S \S 9^{\circ}\right.$ e 10$)$ deixa claramente visível a sua intolerância a tais práticas, e da LC n ${ }^{\circ} 64 / 90$, art. 23. Por isso, o TSE já decidiu que "o bem jurídico tutelado é a normalidade e legitimidade das eleições (CF, art. $14, \S 9^{\circ}$ ) e o interesse público de lisura eleitoral (Lei de Inelegibilidades, art. 23, in fine)." 32

\subsection{Princípios que norteiam a repressão ao abuso de poder nas eleições}

\subsubsection{O princípio da potencialidade}

Por este princípio é que se afere a capacidade de se influir na lisura do processo eleitoral. Deveras, se a coibição ao abuso de poder existe para resguardar a legitimidade da democracia, ele há de ter potencialidade para lesar os postulados que resguardam a lisura dos pleitos.

Este princípio, não raras vezes, tem sido interpretado de maneira distorcida. Atribuem-lhe a característica de exigir uma comprovação matemática de que o abuso, seja de que espécie for, influi no resultado eleitoral. Quem assim procede destrói

31 Escrúpulo \& Poder - $O$ abuso de poder nas eleições brasileiros, Bauru: Edipro, 1995, p. 11.

32 RJSTE 6/1/332-333 e 7/1/278. 
toda a eficácia da repressão ao abuso de poder, por torná-la impossível, por exigir uma verdadeira diabolica probatio.

Deve-se ter em mente que, assim como no direito antitruste,$^{33}$ não estamos diante de uma ciência exata, sendo possível - em virtude do sigilo do voto apenas uma avaliação aproximada. Emerson Garcia põe tudo em seu devido lugar ao lecionar que "para que seja identificada a potencialidade do ato é despicienda a apresentação de cálculos aritméticos que venham a refletir diferença quantitativa de votos em favor de quem praticou; ou mesmo a demonstração de relação de causa e efeito entre o ato, analisado em si e sob a ótica da conjuntura em que foi praticado, denote ser potencialmente daninho à legitimidade do pleito, sendo apto a influir sobre a vontade popular. Bastará, assim, que os motivos convergentes à configuração do abuso de poder superem os divergentes, dando azo à probabilidade de que o ato tenha prejudicado a normalidade do pleito. Desta forma, prebendas de nenhum ou de insignificante valor, inobstante ilícitas e imorais, não terão aptidão para deflagar as medidas referidas." ${ }^{34,35}$

Vejamos a passagem do aditamento ao parecer do MP pelo Vice-ProcuradorGeral Eleitoral, Antônio Fernando Barros e Silva de Souza, no famoso caso em que se julgou um ex-senador: "Lembro, também, que esta Corte tem exigido para o reconhecimento, seja do abuso do poder econômico, seja para a constatação de abuso do poder de autoridade, um nexo de causalidade. Agora, esse nexo de causalidade não pode ser visto como uma comprovação matemática de que o desvio, seja no poder econômico, seja no poder político, influi no resultado eleitoral. Basta, ao ver do Ministério Público - senão a Lei Complementar no 64/90 não terá nenhuma aplicação - que haja a potencialidade do instrumento utilizado para influir no resultado eleitoral... É que a potencialidade dos calendários como veículo de propaganda eleitoral deve ser feita objetivamente, sem qualquer consideração a propósito do elemento subjetivo que inspirou a sua confecção e posterior distribuição". ${ }^{36}$

33 Se no direito antitruste, que tem $n$ dados sobre o mercado, faturamento das empresas etc., a avaliação é aproximada (BRUNA. Sérgio Varella, op. cit., p. 127), a fortiori o será na esfera eleitoral, na qual. além de viger o sigilo do voto ( $\mathrm{CF}$, art. $\left.60, \S 4^{\circ}, \mathrm{II}\right)$, é impossível uma pesquisa auscultando os motivos determinantes do voto de cada eleitor.

34 Abuso de Poder nas Eleiçôes: meios de coibição, Rio de Janeiro: Lumen Juris, 2000, p. 18. Note-se que a edição da Súmula 17 do TSE não altera este quadro porque se trata de infração à lei das eleiçōes (que, como foi muito bem observado pelo TRE/SP, tem natureza administrativa Ac. 134.468, Cadernos de Direito Constitucional e Eleitoral 44/239), e não a repressão ao abuso de poder no proccsso eleitoral, resguardando a lisura c legitimidade dos pleitos, enfim, a democracia. Eis o teor da Súmula 17: Não é admissível a presunção de que o candidato, por ser beneficiário de propaganda eleitoral irregular, tenha prévio conhecimento de sua veiculação. (Arts. 36 e 37 da Lei 9.504, de 30.9.97).

35 Luiz Melíbio Uiraçaba Machado, em interessante trecho de artigo doutrinário, nos explica o motivo desse entendimento: "Isso tudo porque no emprego do poder econômico não há liame entre candidato e eleitor (como se viu); não há imediata relação a determinados eleitores; também não há como indagar dos eleitores, dado o sigilo, as razões de seu voto" ("O Abuso do Poder Econômico no Processo Eleitoral", Resenha Eleitoral, v. 2 - Edição especial, p. 39).

36 Aditamento ao parecer do MP no Acórdão 12.244/PB, RJTSE 7/1/259. No mesmo sentido: RJTSE 4/4/75, 6/3/136-137, 9/4/1 e 10/1/11. 
É por isso que preferimos denominá-lo de princípio da potencialdiade ao invés de nexo causal. ${ }^{37}$

Devemos ter sempre em vista que o processo eleitoral é composto de diversas fases e que qualquer vício em uma de suas fases é suficiente para a deflagração das medidas processuais cabíveis. Assim, a "normalidade e a legitimidade das eleições como um todo pressupõem a normalidade e a legitimidade dos diversos estágios do processo eleitoral, de modo que o comportamento abusivo adotado em determinada fase (da propaganda eleitoral, por exemplo) há de ser apurado e punido, considerando-se a sua aptidão para comprometer aquela fase do processo eleitoral e não obrigatoriamente o resultado final do pleito." 38

Se o ato abusivo desigular os candidatos em cada uma das fases do processo eleitoral, isoladamente ou em todas, não importa, já está configurado o abuso do poder. Não é necessário, assim, que o abuso influa em todo o processo eleitoral ou somente no ato da votação, sendo suficiente para caracterizá-lo sua influência em uma de suas fases, com potencialidade de dano à lisura e à regularidade dos pleitos.

\subsubsection{Da tentativa do abuso}

Faz-se necessário analisar a tentativa do abuso de poder na seara eleitoral. É cabível falar em tentativa de abuso nesta seara? Se for, é punível?

É intuitivo que o conceito de tentativa deve ser haurido do direito penal. $\mathrm{Na}$ tentativa há prática de ato de execução, mas o sujeito não chega à consumação do abuso de poder por circunstâncias alheias a sua vontade. Exemplo de tentativa de abuso seria o caso daquele que comprou vários bens estratégicos para a população de determinado local e estes, antes de serem distribuídos, são apreendidos pelo Poder Judiciário.

Embora seja perfeitamente cabível falar-se em tentativa de abuso, em face do princípio da potencialidade não nos afigura possível a sua punibilidade, sendo necessário ter presente que a coibição do abuso existe para garantir a legitimidade e a igualdade de oportunidades no processo eleitoral. Conduta que não tenha aptidão para desequilibrar a disputa eleitoral (princípio da potencialidade) não pode caracterizar o abuso punível ${ }^{39}$ Assim, como é requisito para a configuração do abuso a potencialidade lesiva do ato, a forma tentada não é punível no direito eleitoral, sendo indiferente a esse ramo do direito público embora, transportando a teoria da tentativa do direito penal, ela exista.

37 Marcelo Silva Moreira (Eleiçōes e Abuso de Poder, Rio de Janeiro: Aide, 1998, 79-82) e Eduardo Antônio Dantas Nobre ("Instrumentos de Impugnação do Diploma: a Ação prevista na Constituição Federal, art. 14, $\$ 10$ e 11, e o Recurso contra a Expedição do Diploma", Resenha Eleitoral, vol. $6, \mathrm{n}^{\circ} 2$, p. 45) nominam este requisito de nexo causalidade. Achamos que é melhor a denominação utilizada por Emerson Garcia (Op. cit., p. 17-19), pois não é necessário um nexo causal e sim uma potencialidade de dano, ainda que ele efetivamente não tenha ocorrido.

38 Trecho do voto do Rel. Min. Marco Aurélio, RJTSE 7/1/272.

39 "Não é punível o desvalor do móvel do agente, mas tão-somente a potencial alteração da situação fática de igualdade dos candidatos" (GARCIA, Emerson, op. cit., p. 40. 
Nossa jurisprudência já teve oportunidade de rechaçar a existência da punibilidade da tentativa do abuso de poder no processo eleitoral diversas vezes. ${ }^{40}$ Vejamos a posição do TSE:

"Abuso do poder econômico. Inexigível se demonstrar a existência de relação de causa e efeito entre a prática tida como abusiva e o resultado das eleições. Necessário, entretanto, se possa vislumbrar a potencialidade para tanto. Não reconhecendo o acórdão regional esteja suficientemente provado tenha havido a distribuição de bens, prática que se pretende configuradora do abuso do poder econômico, não se pode afirmar que esse tenha verificado pelo fato de terem sido apreendidas cestas de alimentos no Comitê Eleitoral. O fato mesmo na apreensão impediu houvesse a influência capaz de comprometer a legitimidade das eleiçōes. $O$ abuso não resulta de atos simplesmente preparatórios. ${ }^{41}$

\subsubsection{O princípio da impersonalidade}

Para compreender este princípio é preciso ter em mente que, normalmente, quem abusa de seu poder o faz para terceiros. Não se pode confundir quem abusa do poder e quem é por ele beneficiado. "O ordenamento pátrio não agasalha o princípio da personalidade, punindo tanto o praticante quanto o beneficiário do ato (art. 22, XIV, da $\left.\mathrm{LC} n^{\circ} 64 / 90\right)$." 42

E o benefíco não é necessarimente para candidatos (pessoas), pode ser também para partidos. Estes podem ser beneficiados pelo abuso de poder em suas diversas formas de manifestação. Qualquer ato que caracterize o abuso para promover ou denegrir partidos, mormente em face das eleições proporcionais, será punido. Por isso, correta a previsão do caput do art. 22 da Lei de Inelegibilidades quando diz que $o$ abuso pode ter como beneficiário o candidato ou partido.

Provado o abuso de poder, deve-se decretá-lo sem necessidade do elemento subjetivo. $O$ beneficiário pode até desconhecer a conduta de quem abusa que, mesmo assim, será responsabilizado.

40 Cf. TSE, REsp n 9.350, Ac. $n^{\circ} 11.899$, j. em 02.4.92, DJU 26.05.92, p. 7.473 (RJTSE 4.2.11), no qual o Min. Villas Boas asseverou em seu voto que "ainda que se admita ter havido a intenção de abusar do poder político, essa intenção ficou apenas na tentativa, pois a prova de que a encomenda se fizera à conta da Assembléia legislativa do Estado (cf. fl. 33) restou elidida". O TRE-MA seguindo a mesma trilha já decidiu que "A mera aquisição de máquina de beneficiamento de arroz, ainda que tenha sido da responsabilidade dos recorrentes, no intuito de trazer-lhes repercussão favorável junto ao eleitorado, não configura abuso de poder econômico, haja vista sua utilização que não chegou a se consumar permanecendo a conduta apenas no campo da tentativa" (in RJTSE $9 / 3 / 122)$.

41 RJTSE 10/2/202-203, sem grifos no original.

42 GARCIA, Emerson, op. cit., p. 19. Nesse sentido, cf. também Luiz Melíbio Uiraçaba Machado,

"O Abuso do Poder Econômico no Processo Eleitoral", Resenha Eleitoral, v. 2 - Edição especial, p. 40. 
Como grande valor que é, a legitimidade do processo eleitoral não poderia ficar a mercê da comprovação do elemento subjetivo, isto é, da comunhão de interesses de quem é beneficiado pela prática de abuso de poder. Não se trata de Direito Sancionador (= punitivo), mas sim de forma de se descontituir o mandato obtido de forma abusiva.

Firme, nesse sentido, a jurisprudência do TSE:

"Recurso especial. Ação de impugnação de mandato eletivo. Abuso do poder econômico. Responsabilidade do candidato beneficiado. Prescindibilidade. Nexo de causalidade. Matéria fática.

1.A penalidade de perda do mandato, decorrente da procedência da ação de impugnação de mandato eletivo, não possui natureza criminal, sendo mera consequiência do comprometimento da legitimidade da eleição por vícios de abuso de poder econômico, corrupção ou fraude. Precedentes.

2.Configurado o abuso de poder econômico por meio do exame de provas, é irrelevante para a procedência da ação de impugnação de mandato eletivo a comprovação da participação direta dos beneficiários nos atos e fatos caracterizadores da prática ilícita.

3.Para dissentir do aresto regional que entendeu provados os fatos apontados e haver nexo de causalidade entre esses e o resultado do pleito, imprescindível o reexame e a valoração do conjunto probatório. Súmula 279/STF. Recurso especial não conhecido." ${ }^{43}$

Embora improvável mas não impossível de ocorrer, é o fato de uma pessoa ou grupo de pessoas fazer propaganda eleitoral com abuso de poder, para candidato que está virtualmente eleito, somente para prejudicá-lo em eventual Ação de Impugnação de Mandato Eletivo. Não defendemos a idéia de que, se um candidato tem a maioria nas intenções de votos, ele possa abusar do poder ou ser por ele beneficiado, mas sim que se o benefício for com o propósito deliberado de o prejudicar, ele deverá se resguardar na Justiça Eleitoral para que o abuso seja estancado, sob o risco de caracterizar-se o abuso com as consequiências daí advindas.

\subsection{Espécies de abuso de poder no processo eleitoral}

O Poder é multiforme, mas a doutrina e a legislação têm percebido que ele normalmente se exterioriza através do meio político, econômico e da mídia. Mas nem sempre foi assim.

43 TSE, REsp n 15.891/BA, Ac. 15.891/BA, Rel. Min. Maurício Corrêa, j. em 11.11.1999, DJU 17.12.1999, p. 171. Nesse sentido, dentre outros: RJTSE 3/3/240, 3/4/51 e $B E \mathrm{n}^{\circ} \mathrm{s} 328 / 645,426 / 8$ e 446/857. Recentemente, no entanto, o TSE tem feito uma distinção quando o abuso é praticado pelo candidato ou por terceiros em seu benefício. No caso de ser praticado pelo próprio candidato não é necessário uma prova tão forte para provar a possivel influência no processo eleitoral; já no caso do ato ter sido praticado por terceiro, a necessidade daquela prova se impõe (AI $n^{\circ}$ 1.136/MT, Rel. Min. Eduardo Ribeiro, j. em 31.08.1998, DJU 02.10.1998, p. 50). 
O Código Eleitoral (Lei ${ }^{\circ} 4.737 / 65$ ), em seu art. 237 econhecia somente o abuso de poder econômico, desvio ou abuso do poder de autoridade, em desfavor da liberdade de voto. Situação que não se alterou com a promulgação da Constituição de 1967 , que no seu art. 148 determinava que a lei complementar poderia estabelecer outros casos de inelegibilidade visando a preservação: "III - na normalidade e legitimidade das eleições, contra o abuso do poder econômico e do exercício dos cargos ou funções públicas". Alguns anos após, a Lei n $n^{\circ} 7.493 / 86$ - assim como o Código Eleitoral - continuava reconhecendo somente o abuso do poder político e do econômico (art. 23), situação que, a nosso ver, não se alterou com a vinda da Lei $n^{\circ} 7.664 / 88$, que em seu art. 24 anunciava: "O mandato eletivo poderá ser impugnado ante a Justiça Eleitoral após a diplomação, instruída a ação com provas conclusivas de abuso do poder econômico, corrupção ou fraude e transgressões eleitorais”, e muito menos com nossa atual Constituição (art. 14, § $9^{\circ}$ ).

Foi com a vinda da $L C n^{\circ} 64 / 90$ que a legislação finalmente reconheceu ainda que tardiamente - umas das práticas mais daninhas à Democracia: o abuso de poder nos meios de comunicação social (art. 22).

A própria legislação ordinária evoluiu no sentido de reconhecer três espécies de abuso de poder no processo eleitoral; mas, é essa classificação taxativa? Não existem outros meios de abuso de poder no processo eleitoral ou uma mistura tão sutil entre as espécies relacionadas pela Lei de Inelegibilidades ( $L C \mathrm{n}^{\circ} 64 / 90$ ) que ficaria difícil englobar os atos violadores da igualdade nos pleitos e da liberdade de votos em qualquer um delas?

Antes de respondermos esss questões, discorreremos sobre os principais aspectos dessas espécies de poder que são utilizados de maneira abusiva no processo eleitoral.

\subsubsection{Abuso de poder econômico}

O abuso de poder econômico é um dos meios mais característicos de ameaça à lisura dos pleitos eleitorais. Não poderia ser de outra forma numa sociedade cuja base é capitalista e na qual o dinheiro abre todas as portas! "Ao invés de ser disputada a confiança do eleitorado, creditada por precedentes realizações na vida pública, pelo vigor da autêntica liderança política, por um trabalho de persuasão por afinidades de convicções, por solidariedades eimpregnadas, transformam-se em negócios com contraprestações pecuniárias. "44

Lembremos que o princípio que norteia todo o processo eleitoral e que deve ser resguardado é o da igualdade (CRP/76, art. 116, 3, b). O abuso de poder econômico que caracteriza-se pela desarrazoada utilização de recursos materiais (financeiros) da iniciativa privada para fins, principalmente, de propaganda eleitoral, atenta contra a isonomia dos candidatos. Isso porque esta prática exclui na disputa "os candidatos

4 RIBEIRO, Fávila, op. cit., p. 52. 
que não possuam grande disponibilidade econômica, assim como aqueles que não são ungidos por grupos empresariais, interessados em se beneficiar do poder político a ser exercido pelo 'candidato da situação', após eleito." +5

Mas, não raro, o abuso do poder econômico não está só; geralmente, associa-se a outro tipos de manifestação de poder: é a promiscuidade do poder. ${ }^{46}$

Nicolau Dino de Castro e Costa Neto, ${ }^{47}$ Procurador da República, enumera alguns fatores que caracterizam a ocorrência do abuso de poder econômico que interessam ao direito eleitoral: 1) o financiamento de partidos ou candidatos ao arrepio das disposições legais ou instruções do TSE disciplinadoras da matéria: ${ }^{48}$ 2) potencialidade para provocar desequilibrio na disputa; e, consequientemente 3 ) ruptura da lisura e legitimdiade do pleito.

É claro que esses critérios não se apresentam absolutos, não passando de indícios, porque o abuso não tem forma pré-definida, é igual a Proteu, conforme explicaremos adiante. Para se caracterizar o abuso do poder econômico não se deverá entender que sempre haverá descumprimento das resoluções do TSE que disciplinam a matéria ou se exigir a prova da influência do abuso no resultado do pleito, exigências descabidas face ao princípio da potencialidade.

A conseqüência mais nefasta dete tipo de influência no processo eleitoral é o financiamento das campanhas por grupos ilícitos: guerrilha, cartéis de drogas etc.

\subsubsection{Abuso do poder de autoridade ou político-administrativo}

Sabendo que o Poder é delimitado pela Constituição do Estado, é natural que grande parte dele resida no próprio Estado; devido a isto, os ocupantes de cargos governamentais detêm grande parcela de poder em suas mãos. "A parcela de poder atribuída aos administradores é suficientemente capaz de influir e desvirtuar um

45 MOREIRA, Marcelo Silva, op. cit., p. 49.

46 Significativa, sobre este aspecto, passagem da obra do jurista Fávila Ribeiro: "Em certos casos, são os partidos que se defrontam com uma conjuntura que se prenuncia desfavorável e valem-se de um esquema de cartelização econômica disposto a investir copiosos recursos financeiros para atingir a colonização governamental, desde que reservada a posição predominante para um dos seus mais engajados expoentes. A luta eleitoral fica totalmente desvirtuada, mantendo-se o objetivo de conquista política, formando-se um conglomerado ao mesmo tempo político, econômico, social e cultural, impregnando-se de tal ordem, ficando tão íntimas e penetrantes as suas interligaçōes, sem isolar a ação econômica, não sendo então possível distinguir o poder econômico dos demais. Mas é ele a argamassa que a todos congrega e impulsiona, estipendiando-os. E o poder social, caracerizado nas comunicações, pode já ser expressāo de uma correlação antecedente, incorporando-se em um conglomerado para ações conjuntas, formando uma estrutura de múltipla potencialidade" (op. cit., p. 53).

47 "Investigação Judicial Eleitoral", Revista da Procuradoria-Geral da República n 7/157 apud MOREIRA, Marcelo Silva, op. cit., p. 51-52.

48 Para Luiz Melíbio Uiraçaba Machado (Op. cit., p. 40) "o simples uso do poder econômico fora das normas financeiras permitidas já caraceriza o abuso e faz incidir a declaração de inelegibilidade do autor dos fatos e a perda do mandato eletivo do seu beneficiário." 
processo eleitoral. Consubstancia-se, também, numa das práticas que maiores lesões provoca ao erário." 49

É o famoso uso da máquina administrativa. É a apropriação do Estado por grupos privados, que o utilizam para prejudicar concorrentes e agraciar apadrinhados políticos. Os governantes usam o próprio Estado para apoiarem seus candidatos; agora, com a emenda que permite reeleição, sua coibição é o grande desafio na área da repressão ao abuso do poder.

Normalmente, exterioriza-se por meio de inúmeras inaugurações de obras públicas e o principal problema para combatê-lo não está na legislação, mas sim na falta de ética que impera na política nacional. Fávila Ribeiro, com pena de mestre, explicou: "A propaganda política cavalga no dorso das celebrações oficiais de obras concentradas, com as publicidades que as acompanham, envolvendo-se, assim, a máquina estatal na campanha sucessória, tornando-se grosseira a dissimulação feita, por deixar revelada a presunção de ingenuidade ou da complacência a que não se perceba a forma ousada e contundente do abuso de poder que fica assim exuberantemente comprovado". 50

Já dissemos que o conceito de abuso na esfera pública e privada não pode ser simplesmente transferido para o direito eleitoral; entretanto, no caso do poder político, sua caracterização se aproxima do que os administrativistas chamaram de ecesso ou desvio de poder.

Há uma clara violação da moralidade e impessoalidade administrativa, já que se utiliza da máquina estatal para beneficiar determinado candidato ou partido, para fazer um sucessor. O mais interessante é que atualmente existe lei - a nosso ver flagrantemente inconstitucional ${ }^{51}$ - autoriando isso (a parte final do inc. II do art. 73 da Lei 9.504/97), ou seja, autorizando o uso da máquina estatal para financiar campanhas políticas.

A construção de obras no último ano do mandato, a manipulação das receitas orçamentárias são apenas alguns dos meios de se abusar do poder político porque - repetimos - o abuso do poder pode assumir inúmeras formas.

Inobstante, a forma mais comum de configurar-se o abuso de poder político é mediante a propaganda oficial. Tanto é assim que a Lei 9.504/97, em seu art. 74, considera abuso de autoridade a infringência do $\S 1^{\circ}$ do art. 37 da $\mathrm{CF}$. Previsão que a nosso ver não pode servir de per si para julgmento procedente de eventual Ação de Impugnação de Mandato Eletivo (CF, art. 14, § 10) porque o abuso de poder no direito eleitoral pressupõe potencialidade (= nexo de causalidade) do dano.

49 MOREIRA, Marcelo Silva, op. cit., p. 29. Motivo pelo qual Adriano Soares da Costa (Instituições de Direito Eleitoral, $4^{2}$ ed., Belo Horizonte: Del Rey, 2000, p. 325) o relaciona com a improbidade administrativa (Lei 8.429/92).

50 Op. cit., p. 60.

51 BIM, Eduardo Fortunato, CAVALARI, Cláudia, "Uso da Máquina Estatal para fins Eleitorais pelos Agentes Públicos: inconstitucionalidade da autorização do inc. Il do art. 73 da lei 9.504/97", Revista de Direito Administrativo 226/33-58. 
O maior óbice ao seu combate é a investigação pelo Judiciário do âmbito da discricionariedade ${ }^{52}$ do ato administrativo, expressão esta que tem servido para acobertar interesses escusos dos dirigentes do país, tornando o Judiciário um pseudo controlador da lisura do processo eleitoral.

\subsubsection{Abuso de poder nos meios de comunicação social}

Com o avanço da tecnologia da informação, sobretudo nas últimas duas décadas, graças ao advento da tecnologia digital, a comunicação cresceu exponencialmente. Houve um surto, uma expansão muito grande no processo comunicativo social (telefones, televisão, jornais, revistas, internet etc.) de modo unilateral, ou seja, os destinatários somente recebem a informação. A comunicação de massa consolidouse. Por isso, para alguns, a imprensa é conhecida como o quinto poder (o quarto seria o Ministério Público). Tão grande é o seu poder sobre o povo que ela pode derrubar presidentes, manipular as massas para votar em seus defensores etc.

Tocqueville já ressaltava o imenso poder da imprensa: "A liberdade de imprensa não faz seu poder sentir-se apenas sobre as opiniões políticas, mas também sobre todas as opiniões dos homens. Ela não modifica apenas as leis, mas os costumes." 53

Nosso querido Rui Barbosa, em obra que chama a atenção da sociedade para a responsabilidade da mídia, já dizia: “A imprensa é a vista da Nação. Por ela é que a Nação acompanha o que lhe passa ao perto e ao longe, enxerga o que lhe malfazem, devassa o que lhe ocultam e tramam, colhe o que lhe sonegam, ou roubam, percebe onde lhe alvejam, ou nodoam, mede o que cerceiam, ou destroem, vela pelo que the interessa, e se acautela do que a ameaça... Um país de imprensa degenerada ou degenerescente é, portanto, um país cego e um país miasmado, um país de idéias falsas e sentimentos pevertidos, um país que, explorado na sua consciência, não poderá lutar com os vícios que lhe exploram as instituições." 54

Se a mídia é a vista do país, sua utilização irresponsável gera uma colossal potencialidade lesiva à liberdade de voto e à igualdade das condições da disputa eleitoral.

O abuso de poder nos meios de comunicação social tornou-se a maneira mais perigosa de influência no processo eleitoral, mormente se aliada ao abuso do poder cultural. Neste, há o autoritarismo da competência, do conhecimento, da cultura, dizendo que isso é certo ou errado porque a ciência, ou estudiosos o dizem. " ${ }^{55}$ "Em

52 Não por outro motivo chamada, pelo jurista suíço Hans Huber, de "Cavalo de Tróia" do Direito Administrativo (ENTERRÍA. Eduardo García de, La Lucha Contra las Inmunidades del Poder en el Derecho Administrativo, $3^{\text {a }}$ ed., Madrid: Civitas, 1995, p. 24).

53 TOCQUEVILLE, Alexis de, A Democracia na América, São Paulo: Martins Fontes, 1998, p. 207.

54 A Imprensa e o Dever da Verdade, $3^{\mathrm{a}}$ ed., São Paulo: EDUSP, 1990, p. 37-38.

55 "Envolve-se a camada cultural nos centros nevrálgicos das programações governativas, sempre invocando em seu prol uma posição de neutralidade política, arrimando-se quase sempre em postulados técnicos ou científicos para dizimar as discrepâncias, recebendo deferências de infalibilidade em seus equacionamentos, aquebrantando as resistências políticas, ou a isso predispondo" (RIBEIRO, Fávila, op. cit., p. 30-31). 
cada sociedade, há grupos sociais cuja tarefa específica consiste em dotar a sociedade de uma interpretação do mundo. Chamamos tais grupos de intelligentsia... A verdade está circularmente ligada a sistemas de poder, que a produzem e a apóiam." 56

Aliado ao poder cultural, a mídia consegue manipular o povo, formar a opinião pública, ou melhor, manufaturá-la com muito mais facilidade.

Os detentores dos meios de comunicação, manipulando a opinião pública, têm um enorme poder, pois é essa opinião pública que votará nas próximas eleições. Uma imagem negativa passada pelos meios de comunicação pode por a perder todo o investimento posto por um grupo de poder (partido político) num candidato, sendo que o revés também é verdadeiro, o partido político pode ganhar muito, mas muito mesmo, quando há apoio da mídia.

Nota-se aqui muita interferência dos poderes político-administrativo e econômico. É que o Estado é o maior cliente dos meios de comunicação; seu orçamento para este setor, fora os subsídios fiscais e empréstimos, é astronômico. Assim, ele pode influenciar o conteúdo da programação das emissoras de TV e jornais. A própria propaganda institucional, não raras vezes, é meio de propaganda disfarçada. A própria Constituição Federal permite este tipo de propaganda, mas impõe-lhe restrições (art. $37, \S 1^{\circ}$ ), "admitindo aquelas peças que sejam eminentemente informativas, necessárias para alguns finalidades coletiva." 57

O mesmo se diga do poder econômico. Ele mobiliza grande quantidade de capital para anúncios na mídia e, sendo assim, tem grande influência no conteúdo da programação. Por isso Marcelo Silva Moreira considera o "abuso de poder nos meios de comunicação como uma variação, um veículo, sobre o qual se desenvolvem o abuso de poder político-administrativo e o abuso de poder econômico." 58

Alia-se a tudo isso, o fato de todas as concessões de rádio e TV serem dadas pelo Governo, que as distribui entre os Congressistas e a amigos desses, em suma, aos detentores do poder. Obviamente, eles usam esses poder, que lhes foi concedido pelo Estado, para promoverem a si mesmos ou a seus apadrinhados, não tendo nenhum escrúpulo em manipular a massa. Como salienta Lauro Barreto: "Além disso, pelo fato dos nossos meios de comunicação estarem concentrados nas mãos e na esfera de influência de uma seleta, privilegiada e diminuta minoria, esses novos e arrojados métodos de pressões ficam restritos a pouquíssimos grupos, interesses e candidatos, sobrando para os demais apenas a prática dos já superados delitos eleitorais, facilmente detectáveis, que a própria mídia se encarrega de denunciar com grande estardalhaço, não só para desviar atenção da opinião pública dos abusos de poder que ela própria comete, mas também para vender a imagem de alguma preocupação com a lisura do pleito, através da execração pública e do clamor pela punição de alguns poucos e geralmente insignificantes casos de mapismo ou outras irregularidades que, mesmo assim, algum tempo depois, acabam saindo do noticiário

Karl Mannheim apud RIBEIRO, Fávila, op. cit., p. 30.

COSTA, Adriano Soares, Instituições de Direito Eleitoral, p. 327.

Op. cit., p. 59. 
e escapando ilesos da Justiça Eleitoral." ${ }^{59}$ Designa-se o poder dos políticos fundado na mídia de coronelismo eletrônico.

Aqui, a facilidade de se fazer publicidade, ostensiva ou não, é o principal fator de desequilíbrio no processo eleitoral. E por mais paradoxal que isso possa parecer, a imprensa que se esconde atrás da liberdade de expressão e de imprensa, propugnando por sua irresponsabilidade, é a mesma que cobra a responsabilidade de particulares e do Poder Público.

Quem pensa diferente ignora que o poder não provém apenas do Estado, mas está difuso na sociedade, no homem, sendo perfeitamente possível a existência de poder na esfera privada, principalmente na mídia. A imprensa é, sem dúvida, um poder social!

Os meios de comunicação são obrigados a guardar uma atitude de impessoalidade ou neutralidade em todo o processo eleitoral, ${ }^{60}$ respeitando, desta maneira, o princípio da igualdade entre os candidatos e partidos políticos e da liberdade de voto. É claro que há determinados candidatos que conseguem ser notícia e outros não; não é isso, a nosso ver, que configuraria o abuso nos meios de comunicação social.

\section{0 mito de Proteu}

Segundo Campbell ${ }^{61}$ umas das funções do mito é a pedagógia, isso porque eles trazem uma mensagem que é válida para a vida. O mito é uma imagem forte, simbólica. Aristósteles diz que ele tem um caráter metafórico, ${ }^{62}$. Pois procura explicar o que o discurso racional não alcança ou teria dificuldade em atingir. Johann Jakob Bachofen, em opúsculo clássico sobre mitologia, entende que o "mito fraciona um pensamento em diversas imagens conexas, e cede ao receptor a tarefa de extrair as últimas conseqüências de tal conexão", ${ }^{63}$ motivo pelo qual utilizá-lo-emos para melhor exemplificar o que ocorre com o abuso de poder no processo eleitoral.

Deus marinho apelidado de "O velho do mar", Proteu guardava os rebanhos de Netuno (Poseidon), isto é, grandes peixes e focas. Para reocmpensá-lo dos trabalhos que com isso tinha, Netuno deu-lhe o conhecimento do passado, do presente e do futuro. Mas não era fácil consultá-lo, ele se recusava a todos que vinham fazê-lo.

59 BARRETO, Lauro, op. cit., p. 14.

60 BARACHO, José Alfredo de Oliveira, “A Teoria Geral do Direito Eleitoral e seus Reflexos no Direito Eleitoral Brasileiro", Informativo Eleitoral 10/27.

61 CAMPBELL, Joseph, $O$ Poder do Mito, $11^{*}$ ed., São Paulo; Palas Athena, 1994, p. 32. "Aquela palavra por muito tempo tida como inútil por ingênua e fantasiosa (o mito), revela-se aos homens do nosso século como dotada de uma apaixonante sabedoria que emerge do coração, do encontro com a natureza, com as divindades e com os outros homens" (MORAIS, Régis de (Org.), As Razões do Mito, São Paulo; Papirus, 1988, p. 9).

62 ALMEIDA, Maria da Piedade Eça de, “Mito Metáfora Viva?", in MORAIS, Régis de (Org.), As Razóes do Mito, p. 66.

63 Mitologia Arcaica y Derecho Materno, Barcelona: Anthropos, 1988, p. 39, tradução livre. 
Diz o mito que para fazê-lo falar era preciso surpreendê-lo durante o sono, e amarrá-lo de maneira que não pudesse escapar, pois ele tomava todas as formas para espantar e/ou ludibriar os que se aproximavam: ${ }^{64}$ a de leão, dragão, leopardo, javali etc.; algumas vezes se metamorfoseava em árvore, em água e mesmo em fogo; mas se se perseverava em conservá-lo bem apertado, retomava a primitiva forma $e$ respondia a todas as perguntas que se lhe fizessem.

Em suma, quando não queria revelar o futuro aos mortais, metamorfoseava-se em água, fogo ou em animais variados, com o fim de se furtar às questões terrenas. Para obter sucesso na consulta era necessário ter coragem, para não se assustar com as formas que tomava, e força para segurá-lo.

\section{O polimorfismo do abuso de poder no direito eleitoral e o mito de Proteu}

Algo muito semelhante ocorre na seara eleitoral com o abuso de poder, que tradicionalmente é classificado em político, econônomico, e nos meios de comunicação (art. 22 da Lei n ${ }^{\circ} 64 / 90$ ). Ele tem o dom da metamorfose (assim como Proteu), podendo assumir várias formas para que a Justiça Eleitoral (mortais) não o descubra. Somente uma Justiça forte - porque poderá impor coativamente suas decisões ${ }^{65}$ e corajosa conseguirá descobri-lo e puni-lo.

Às vezes, de nada adianta tentar enquadrá-lo na rígida classificação do art. 22 da $\operatorname{LC} n^{\circ} 64 / 90$, porque ele assumirá outra forma que não a prevista na legislação ou apresentar-se-á de forma hibrida, dificultando a rígida classificação em algumas das espécies previstas na Lei de Inelegibilidades.

Não existe forma fixa, uma fórmula pela qual é possivel detectar o abuso de poder no processo eleitoral; muito pelo contrário, o abuso de poder, seja ele de qual espécie for, é forma maleável de se burlar a legitimidade das urnas. É caracerizado não pelos seus meios, que podem ser abuso do poder econômico, dos meios de comunicação ou o político, dentre outros, mas sim por sua lesividade à legitimidade nas eleições. O rol do art. 22 da LC 64/90 é exemplificativo!

Essa característica do abuso de poder foi muito bem notada pelo sempre citado Fávila Ribeiro, in verbis: "Na hipótese teria sido mais vantajosa a supressão de especificação dos poderes, simplificando-se com um enunciado que transmitisse generalizada abrangência, mencionando apenas - contra qualquer forma de abuso de poder à lisura do processo eleitoral. Ter-se-ia de levar em consideração o

64 HACQUARD, Georges, Dicionário de Mitologia Grega e Romana, Lisboa: Asa, 1996, p. 249, verbete: proteu; GUIMARÃES, Ruth, Dicionário de Mitologia Grega, São Paulo: Cultrix, 1972, p. 266, verbete: proteu; BARTRA, Agusti, Dicionario de Mitologia, Barcelona: Grijalbo, 1985, p. 164, verbete: proteo; SCHMIDT, Jöel, Dicionário de Mitologia Grega e Romana, Lisboa: Edições 70, 1995, p. 229, verbete: proteu; KURY, Mário da Gama, Dicionário de Mitologia Grega e Romana, $2^{2}$ ed., Rio de Janeiro: Jorge Zahar Editor, 1992, p. 341, verbete: proteu.

65 ALCALÁ-ZAMORA Y CASTILlO, Niceto. Processo, Autocomposición y Autodefensa (Contribución al estudio de los fines del proceso), 3* ed., 1" reimp., México: UNAM, 2000, p. 14. 
resultado lesivo ao processo eleitoral, na seqüência das fases e atos que o compõe, inquinando a sua autenticidade por qualquer modalidade de abuso de poder. Pretendemos, assim, ficasse esclarecido que o sentido literal das normas não é capaz de inibir o sentido amplo da ilicitude eleitoral, sendo aplicáveis as sançōes previstas para abusos de todo e qualquer tipo de poder prevalecendo o saudável e consagrado principio de hermenêutica de que o espírito sobreleva à forma, subordinando-se os meios aos fins ou seja, a letra da lei deve ser entendida harmonizada com os aspectos teleológicos explicitados. $" 66$

Adilson Abreu Dallari também sentiu o polimorfismo do abuso de poder no direito eleitoral - na seara política — quando disse que "não há como relacionar, em numerus clausus as condutas tipificadas como configuradoras de abuso de oder político." 67

Aqui está o fundamento geral da coibição do abuso de poder no processo eleitoral: o resguardo da legítima manifestação popular nas urnas, garantindo a igualdade de competição e de equilíbrio entre partidos e candidatos, a fim de que haja um aperfeiçoamento do processo eleitoral e a plena concretização da democracia representativa.

Nunca é demais repetir, apesar do abuso no direito eleitoral normalmente se manifestar pelos poderes econômico, político e dos meios de comunicação, que ele tem o dom de Proteu: pode se revestir de qualquer forma.

O abuso muda de forma para que a Justiça Eleitoral não possa detectá-lo, mas se a Justiça persiste na sua luta em prol da legitimidade dos pleitos, ela certmente o identificará, mesmo que seja em outra forma não prevista na classificação da Lei das Inelegibilidades (LC $\mathrm{n}^{\circ}$ 64/90, art. 22).

Já dizia o ilustre jusfilósofo argentino Genaro Carrió, eu as classificações não são certas ou erradas, mas sim úteis ou inúteis. ${ }^{68}$ De nada adianta classificar o abuso de poder no processo eleitoral, como fez a $L C n^{\circ} 64 / 90$, se uma conduta que afeta

66 RIBEIRO, Fávila, op. cit., p. 51.

67 DALLARI, Adilson Abreu, "Abuso de Poder Político", in Direito Eleitoral, Coordenadores: Carlos Mário da Silva Velloso e Cármen Lúcia Antunes Rocha, Belo Horizonte: Del Rey, 1996, p. 250.

68 "Las classificaciones no son ni verdadeiras ni falsas, son serviciales o inutiles; sus ventajas o desventajas están supeditadas al interés que guía a quien las formula, y a su fecundidad para presentear un campo de conocimiento de una manera más facilmente comprensible o más rica en consecuencias práticas deseables. Siempre hay múltiples maneras de agrupar o clasificar un campo de relaciones o de fenómenos; el criterio para decidirse por una de ellas no está dado sino por consideraciones de conveniencia cientifica, didáctica o prática. Decidirse por una clasificación no es como preferir un mapa fiel a uno que no lo es. Porque la fidelidad o infidelidad del mapa tiene como test una certa realidad geográfica, que sierve de tribunal inapelable, com sus rios, cabos y cordilleras reales, que el buen mapa recoge y el mapa olvida. Decidirse por una clasificación es más bien como optar por el sistema métrico decimal frente al sistema de medición de los ingleses. $\mathrm{Si}$ el primeiro es preferible al segundo no es porque aquél sea verdadeiro y éste falso, sino porque el primero es más cómodo, más fácil de manejar y mas apto para satisfazer com menor esfuerzo ciertas necesidades o conveniencias humanas" (CARRIÓ, Genaro R., Notas sobre Derecho y Lenguaje, 4" ed., Buenos Aires: Abeledo-Perrot, 1990, p. 99). 
- princípio da potencialidade - a legitimidade do pleito não é coibida porque não se enquadra na rígida classificação legal.

A classificação utilizada pela Lei da Inelegibilidades (art. 22) apresenta-se útil na medida em que não se entenda como tal um rol taxativo das formas de abuso, porque isso seria torná-la inútil para combatê-lo, ou seja, para manter a legitimidade e a igualdade de nossos pleitos. A interpretạção da lei deve-se fazer da Constituição (liberdade de voto e igualdade e moralidade no processo eleitoral) para legislação ordinária (LC 64/90) e não ao contrário.

No Brasil, vigora o sistema jurisdicional ${ }^{69}$ de controle das eleições, cabendo ao Judiciário controlar a legitimidade e lisura de nossos pleitos. Por isso, não podemos amesquinhar o alcance do seu controle sobre as eleições porque a legitimidade do sistema democrático republicano depende da lisura do processo eleitoral, somente alcançada quando todas as fases do processo estão isentas dos vícios que contaminam a liberdade de voto e maculam a isonomia entre os concorrentes ao pleito.

\subsection{Outros casos de abuso de poder no processo eleitoral.}

Uma das espécies de abuso mais daninho à democracia é o praticado no casuísmo e na manipulação da legislação eleitoral: ${ }^{70}$ abuso do poder legislativo.

Exemplo vivo deste fato, e que infelizmente foi constitucionalizado (art. 45, $\S$ $1^{\circ}$ ), é a alteração do número de deputados federais por Estado (representatividade distorcida), para que, proporcionalmente, fosse diminuída a representatividade das regiões mais desenvolvidas e politizadas do país, através de um aumento substancial das bancadas do Nordeste e Norte, onde a falta de informação e desenvolvimento, possibilitam a prática do coronelismo e outras mais nefastas à legitimação dos mandatos.

Esse é o típico argumento ad terrorem para se reconhecer a existência de normas constitucionais inconstitucionais (Otto Bachof, Normas Constitucionais Inconstitucionais?; Paulo Thadeu Gomes da Silva, Poder Constituinte Originário e sua Limitação Material pelos Direitos Humanos). Mas isso é questão praticamente superada em face do entendimento do STF, que não reconhece a existência de normas constitucionais inconstitucionais. ${ }^{71}$

69 GOMES, Suzana de Camargo, A Justiça Eleitoral e sua Competência, São Paulo: Revista dos Tribunais, 1998, p. 23, 38-40.

70 Lauro Barreto (Op. cit, p. 19) transcreve as seguintes consideraçōes de Hilda Soares Braga (Sistemas Eleitorais do Brasil, Brasília: Senado Federal, 1990): "A manipulação da legislação eleitoral visando o favorecimento e a continuidade daqueles que se encontram no poder é uma constante na história política do Brasil. As mudanças no sistema eleitoral sempre ocorreram para atender aos interesses da classe dominante. Os chamados casuísmos eleitorais não foram privilégio do regime militar de 1964, embora estes tenham sido em maior quantidade, sempre existiram, desde o Império."

71 Obviamente, o Poder Constituinte Originário é limitado pela legitimidade, não podendo ser usado - como foi - para outros fins que não o bem comum do povo, o interesse público. Princípio básico da democracia, decorrente do direito fundamental da igualdade (da representaçāo política), 
De qualquer maneira, ainda restam as normas editadas pelo poder derivado ou reformados (principalmente EC e leis complementares e ordinárias).

Um exemplo concreto: houve punição de um Senador por mandar imprimir, na gráfica do Senado Federal, e distribuir - utilizando-se da cota do correio a que tinha direito como Senador - 130.000 calendários para fins eleitorais. O TSE considerou abuso de poder de autoridade (político) e julgou procedente a Ação de Investigação Judicial Eleitoral contra o citado Senador, declarando-lhe a inelegibilidade e cassando seu registro para as eleições subseqüentes. ${ }^{72}$ Por conta desta condenação, o Congresso Nacional, em um dos momentos mais baixos de sua vida institucional, confeccionou a chamada Lei da Impunidade (LC n- 86/96), instituindo a Ação Rescisória Eleitoral com efeito suspensivo automático (possibilitava o exercício do mandato eletivo até o seu trânsito em julgado). Fato que foi prontamente rechaçado pelo nosso Judiciário em sede cautelar ${ }^{73}$ e depois confirmada no mérito. ${ }^{74}$

Outro exemplo corriqueiro é o desvio que ocorre nas chamadas lei do ano. Sendo os próprios parlamentares que elaboram tais leis os mesmos que disputarão,

é o que garante a "cada cidadão, um voto". Um país e Constituição que se dizem democráticos não podem distorcer isso no sistema representativo proporcional. Por isso, data maxima venia, não concordamos com o STF quando, entendendo de maneira diversa (ADIn $n^{\circ}$ 815-3/DF, v.u., Rel. Min. Moreira Alves, j. em 28.03.1996, $R T$ 732/147), rejeitou o pedido de inconstitucionalidade do disposto no $\S 1^{\circ}$ e $2^{\circ}$ do art. 45 da Magna Carta, sob os seguintes argumentos: "A tese de que há hierarquia entre normas constitucionais originárias dando azo a declaração de inconstitucionalidade de umas em face de outras é incompossível com o sistema de Constituição rígida. Na atual Carta Magna "compete ao Supremo Tribunal Federal, precipuamente, a guarda da Constituição" (artigo 102, caput), o que implica dizer que essa jurisdição lhe é atribuída para impedir que se desrespeite a Constituição como um todo, e não para, com relação a ela, exercer o papel de fiscal do Poder Constituinte originário, a fim de verificar se este teria, ou não, violado os princípios de direito suprapositivo que ele próprio havia incluído no texto da mesma Constituição. Por outro lado, as cláusulas pétreas não podem ser invocadas para sustentação da tese da inconstitucionalidade de normas constitucionais inferiores em face de normas constitucionais superiores. porquanto a Constituição as prevê apenass como limites ao Poder Constituinte derivado ao rever ou ao emendar a Constituição elaborada pelo Poder Constituinte originário, e não como abarcando normas cuja observância se impôs ao próprio Poder Constituinte originário com relação às outras que não sejam consideradas como cláusulas pétreas, e, portanto, possam ser emendadas. Ação não conhecida por impossibilidade jurídica do pedido."

O poder constituinte não poder ir tão longe a ponto de negar a missão primária do Estado, o bem-comum juridicizado no respeito aos direitos fundamentais do cidadão. Giorgio del Vechio bem relata isso: "A constante tutela dos direitos naturais da pessoa é, por conseguinte, o fim imutável do Estado, a missão primária que êste é chamado a cumprir, e à qual não pode subtrair-se sem se privar do título que justifica a sua existência. Em todos os momentos de sua ação, não pode o Estado prescindir daquela sua fundamental "razao de ser", que representa, a um tempo, seu princípio e fim" (Teoria do Estado. São Paulo: Saraiva. 1957, p. 1.000, grafia no original). Nesse sentido, cf. ainda a esxcelente obra de Paulo Thadeu Gomes da Silva, Poder Constituinte Originário e sua Limitação Material pelos Direitos Humanos.

72 TSE, Recurso n 12.244/PB, RJTSE 7/1/251.

73 STF, Pleno, v.u., ADInMC n 1.459-5/DF, Rel. Min. Sydney Sanchez, j. em 30.05.1996, DJU 3.10.1997, p. 49.227.

74 STF, Pleno, ADIn n 1,459-5/DF, j. 17.03.99, RSTF-LEX 247/24 e RTJ 169/15. 
em busca da reeleição, os pleitos eleitorais por elas regulamentadas, as possibilidades de desvio de poder na função legislativa são enormes e freqüentes, o casuísmo e o corporativismo chegam a assustar. Roque Carrazza, emérito professor da PUC-SP, ao tratar da necessidade do legislador ater-se ao legítimo interesse público na confecção da lei, nos ensinou que este "Quando exercita sua competência de acordo com interesses subalternos (v.g., os meramente partidários). afastando-se dos fins superiores que lhe são apontados pela Constituição, comete verdadeiro desvio de poder." 75

Provado que a alteração legislativa desviou-se dos poderes outorgados pelo povo, impõe-se o reconhecimento da nulidade do ato praticado com base nessa pseudo legislação. O dogma do poder absoluto do legislador infraconstitucional caiu por terra com o advento do constitucionalismo; é pacífica a tese da existência do abuso de poder na função legislativa. ${ }^{76}$

Outra forma de abuso de poder em matéria eleitoral é o contido na religião: abuso de poder religioso. Imaginemos uma cidade onde o número de eleitores de determinada religião seja significativo e um candidato seja apoiado por um grande expoente dessa mesma religião, de preferência um eclesiástico com prestígio na cidade. Se este clérigo, nas suas missas, no palanque eleitoral ou em outro lugar, usando de seu enorme poder carismático (Max Weber), fizer campanha para determinado candidato, certamente essa campanha terá a potencialiade de desequilibrar a eleição, caracterizando, assim, o abuso a ser coibido pela Justiça Eleitoral.

Aqui deixamos a pergunta: essas duas espécies de abusos de poder no Direito Eleitoral - que diante da riqueza factual da vida não exclui outras espécies —, só porque não estão previstos no art. 22 da Lei de Inelegibilidades, não poderão ser consideradas como tal? Elas não existem para o mundo jurídico?

\section{Conclusão}

Sendo a Democracia um regime erigido na isonomia dos seus membros e na soberania popular, é mister conceituar o abuso de poder na seara eleitoral em função de seu fim, qual seja, o de turvar a isonomia entre os candidatos (igualdade de condições na disputa) e a liberdade de voto, com a conseqüente mácula à legitimidade da representação popular. Faz-se necessário empreender uma filtragem constitucional na classificação da Lei de Inelegibilidade, compreendendo o abuso de poder em rezão de seus fins, a conspurcação da legitimidade - requisito da Democracia.

75 Curso de Direito Constitucional Tributário, $15^{\mathrm{a}}$ ed., p. 251. Segundo doutrina A. Gordillo (Tratado de Derecho Administrativo, t. III), "três são os casos através dos quais se manifesta o desvio de poder: "o funcionário atua com uma finalidade pessoal, o funcionário atua com a finalidade de beneficiar terceiros, o funcionário atua com a finalidade de beneficiar a Administração" (LEITE, Luciano Ferreira, Discricionariedade Administrativa e Controle Judicial, São Paulo: Revista dos Tribunais, 1981, p. 61, nota 19).

76 Sobre esse tema, cf. excelente estudo desenvolvido por Pedro Estevam A. P. Serrano, O Desvio de Poder na Função Legislativa, São Paulo: FTD, 1997. 
Mesmo levando em conta a sábia advertência dos romanos em relação ao direito civil, mas que é válida para todo o Direito, ominis definitio in jure civili periculosa est, podemos definir o abuso de poder no processo eleitoral como aquela conduta, ou condutas, que, independente dos meios ou da fase do processo eleitoral, têm aptidão (potencialidade) para deturpar o resultado das urnas, caracterizando, assim, sua lesividade à legitimidade nas eleições.

É importante ter em mente que os fins preponderam, e os meios, desde que potencialmente lesivos e ainda que "lícitos" em si mesmos - autorizados pelo Direito Estatal -, deixam de sê-lo se o emprego do poder visou obter vantagens eleitorais.

A classificação utilizada pela Lei de Inelegibilidades (art. 22) apresenta-se útil na medida em que não se entenda por útil um rol taxativo das modalidades de abuso, ou se imprima uma interpretação restritiva na hora de captá-lo da riqueza dos fatos sociais. Isso porque a luta contra o abuso deveria apresentar-se em uma fórmula genérica que expressasse o fato de que qualquer utilização indevida do poder, tanto o público como o privado, deveria ser coibida se tivesse aptidão (potencialidade) para violar o princípio da igualdade entre os candidatos, deslegitimando o processo eleitoral e a consequiente democracia provinda da regularidade deste.

Em suma, não se pode engessar o Judiciário - que se apresenta diretamente diante dos múltiplos fatos sociais - com palavras abstratas que almejam ser infalíveis e válidas a todo o momento. Não podemos nos deixar limitar a certas fórmulas legais que prevêem determinadas espécies de abuso de poder no processo eleitoral pois esse abuso é igual ao personagem mitológico Proteu: pode assumir qualquer forma, ou seja é polimorfo.

A dificulade teórica para se enquadrar determinada conduta na didática, porém não exaustiva, classificação do art. 22 da $L C n^{\circ}$ da $L C n^{\circ} 64 / 90$ não constitui óbice ao reconhecimento do abuso na seara eleitoral. Deve a Justiça Eleitoral ter coragem de "segurá-10" até que ele mostre sua verdadeira face, a de macular o processo eleitoral, obstruindo, desta forma, a existência da verdadeira democracia.

\section{Referências bibliográficas}

ALCALÁ-ZAMORA Y CASTILLO, Niceto. Processo, Autocomposición y Autodefensa (Contribución al estudio de los fines del proceso). $3^{\mathrm{a}}$ ed. $1^{\mathrm{a}}$ reimp. México: Universidad Nacional Autónoma de México, 2000.

ALCUBILlA, Enrique Arnaldo. El Régimen Electoral de España. Madrid: Centro de Estudios Politicos y Constitucionales, 1999.

ALMEIDA, Maria da Piedade Eça de. "Mito: Metáfora viva?" In: As Razões do Mito. Organizador: Régis de Morais. São Paulo: Papirus, 1988.

ALVIM NETO, José Manoel Arruda. "A Liminar na Ação Cautelar e a Suspensão da Exigibilidade do Crédito Tributário." In: Repertório de Jurisprudência e Doutrina sobre Processo Tributário. Coordenadora: Teresa Arruda Alvim. São Paulo: Revista dos Tribunais, 1994.

ATALIBA, Geraldo. República e Constituição. $2^{\text {a }}$ ed. São Paulo: Malheiros, 1998. BACHOF, Otto. Normas Constitucionais Inconstitucionais? Coimbra: Almedina, 1994. 
BACHOFEN, Johann Jakob. Mitologia Arcaica y Derecho Materno. Barcelona: Anthropos, 1988.

BARACHO, José Alfredo de Oliveira. "A Teoria Geral do Direito Eleitoral e seus Reflexos no Direito Eleitoral Brasileiro." Informativo Eleitoral $\mathrm{n}^{\circ} 10$, Campo Grande: TRE/MS, 1998.

BARBOSA, Rui. A Imprensa e o Dever da Verdade. $3^{\text {a }}$ ed. São Paulo: EDUSP, 1990.

BARILE, Paolo. Corso di Diritto Constituzionale. $2^{\mathrm{a}}$ ed. Padova: CEDAM, 1964.

BARRETO, Lauro. Escrúpulo \& Poder - O abuso de poder nas eleições brasileiras. Bauru: Edipro, 1995.

BARTRA, Agusti. Diccionario de Mitologia. Barcelona: Grijalbo, 1985.

BASTOS, Celso. Comentários à Constituição do Brasil. São Paulo: Saraiva, 1990, $1^{\circ}$ vol.

BIM, Eduardo Fortunato, CAVALARI, Cláudia. "Uso da Máquina Estatal para fins Eleitorais pelos Agentes Públicos: inconstitucionalidade da autorização do inc. II do art. 73 da Lei 9.504/97". Revista de Direito Adininistrativo $n^{\circ} 226$.

BRUNA, Sérgio Varella. O Poder Econômico e a Conceituação do Abuso em seu Exercício. São Paulo: Revista dos Tribunais, 1997.

CAMPBELL, Joseph. O Poder do Mito. $11^{\mathbf{a}}$ ed. São Paulo: Palas Athena, 1994.

CANOTILHO, J. J. Gomes. Direito Constitucional. 6a ed. Combra: Almedina, 1996. , MOREIRA, Vital. Fundamentos da Constituição. Coimbra: Coimbra Editora, 1991.

CARRAZZA, Roque A. Curso de Direito Constitucional Tributário. $15^{\mathrm{a}}$ ed. São Paulo: Malheiros, 2000.

CARRIÓ, Genaro R. Notas sobre Derecho Y Lenguaje. $4^{\mathrm{a}}$ ed. Buenos Aires: Abeledo-Perrot, 1990.

COSTA, Adriano Soares. Instituiçōes de Direito Eleitoral. $4^{\mathrm{a}}$ ed. Belo Horizonte: Del Rey, 2000.

DALlARI, Adilson Abreu. “Abuso de Poder Político." In: Direito Eleitoral. Coordenadores: Cármen Lúcia Antunes Rocha e Carlos Mário da Silva Velloso. Belo Horizonte: Del Rey, 1996.

ENTERRÍA, Eduardo Garcia de. La Lucha Contra las Inmunidades del Poder en el Derecho Administrativo. $3^{\mathrm{a}}$ ed. Madrid: Civitas, 1995.

FARIA, José Eduardo. Poder e Legitimidade. São Paulo: Perspectiva, 1978.

GALBRAITH, J. Kenneth. Anatomia do Poder. $3^{\text {a }}$ ed. São Paulo: Pioneira, 1989.

GARCIA, Emerson. Abuso de Poder nas Eleições: Meios de coibição. Rio de Janeiro: Lumen Juris, 2000.

GOMES, Suzana de Camargo. A Justiça Eleitoral e sua Competência. São Paulo: Revista dos Tribunais, 1998.

GUIMARÃES, Ruth. Dicionário de Mitologia Grega. São Paulo: Cultrix, 1972.

HACQUARD, Georges. Dicionário de Mitologia Grega e Romana. Lisboa: Asa, 1996.

KURY, Mário da Gama. Dicionário de Mitologia Grega e Romana. 2a ed. Rio de Janeiro: Jorge Zahar Editor, 1992. 
LEITE, Luciano Ferreira. Discricionariedade Administrativa e Controle Judicial. São Paulo: Revista dos Tribunais, 1981.

MACHADO, Luiz Melibio Uiraçaba. " $O$ Abuso do Poder Econômico no Processo Eleitoral." Resenha Eleitoral, vol. 2 (Edição especial), Florianópolis: TRE/SC, 1995.

MEIRELLES, Hely Lopes. Direito Administrativo Brasileiro. $26^{\circ}$ ed. São Paulo: Malheiros, 2001.

MENDES, Antônio Carlos. "Apontamentos sobre o Abuso de Poder Econômico em Matéria Eleitoral." Cadernos de Direito Constitucional e Eleitoral no 3.

MONTEIRO, Washington de Barros. Curso de Direito Civil. 32a ed. São Paulo: Saraiva, 1994, $1^{\circ}$ vol. (Parte Geral).

MORAIS, Régis de (Org.). As Razões do Mito. São Paulo: Papirus, 1988.

MOREIRA, Marcelo Silva. Eleições e Abuso de Poder. Rio de Janeiro: Aide, 1998.

MOREIRA NETO, Diogo de Figueiredo. Teoria do Poder. São Paulo: Revista dos Tribunais, 1992.

NAVES, Lúcio Flávio de Vasconcellos. Abuso no Exercício do Direito. Rio de Janeiro: Forense, 1999.

NOBRE, Eduardo Antônio Dantas. "Instrumentos de Impugnação do Diploma: a Ação prevista na Constituição Federal, art. 14, \$\$10 e 11, e o Recurso contra a Expedição do Diploma." Resenha Eleitoral, vol. 6, $\mathrm{n}^{\circ}$ 2, Florianópolis: TRE/SC, 1999.

NOGUEIRA, Ataliba. Lições de Teoria Geral do Estado. São Paulo: Revista dos Tribunais, 1969.

REALE, Miguel. Teoria do Direito e do Estado. $4^{\text {a }}$ ed. São Paulo: Saraiva, 1984.

RIBEIRO, Fávila. Abuso de Poder no Direito Eleitoral. $3^{a}$ ed. Rio de Janeiro: Forense, 1998.

ROCHA, Cármen Lúcia Antunes. "Democracia, Constituição e Administração." Revista Trimestral de Direito Público ${ }^{\circ} 26$.

SCHIER, Paulo Ricardo. Filtragem Constitucional - Construindo uma nova dogmática jurídica. Porto Alegre: Sérgio Antônio Fabris Editor, 1999.

SCHMIDIT, Jöel. Dicionário de Mitologia Grega e Romana. Lisboa: Edições 70, 1995.

SILVA, Paulo Thadeu Gomes da. Poder Constituinte Originário e sua Limitação Material pelos Direitos Humanos. Campo Grande: Solivros, 1999.

SOARES, Murilo C. "Televisão e Democracia." In: Mídia, Eleições e Democracia. Heloíza Matos e outros. São Paulo: Scritta, 1994.

SOUSA, Daniel Coelho de. Interpretação e Democracia. $2^{\mathbf{a}}$ ed. São Paulo: Revista dos Tribunais, 1979.

SOUZA, José Pedro Galvão de. Iniciação à Teoria do Estado. $2^{\mathrm{a}}$ ed. São Paulo: Revista dos Tribunais, 1976.

TOCQUEVILLE, Alexis de. A Democracia na América. São Paulo: Martins Fontes, 1998.

O que é Democracia? 2a ed. Petrópolis: Vozes, 1996.

VECHIO, Giorgio del. Teoria do Estado. São Paulo: Saraiva, 1957. 


\title{
Proteção ao Processo
}

\author{
Rosana Josefa Martins Dias
}

ROSANA JOSEFA MARTINS DLAS

PROTECAO

AO

PROCEsso

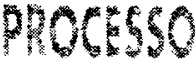

I)

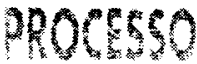

W THOMan
Ref. 0066

Form. 14x21
Brochura

1994
155 págs.

\section{Questões Controvertidas de Locação e Condomínio}

Geraldo Beire Simões

Este livro reúne algumas das diversas publicações de artigos jurídicos de autoria do advogado Geraldo Beire Simôes, especializado em Direito Imobiliário, em vários órgãos de divulgação, versando sobre variadas questões controvertidas de locação, principalmente, e condominiais, além de trabalhos sobre a recente reforma do $\mathrm{CPC}$ e questōes diversas.

Ref. 0128

Form. 14x21
Brochura 1997
260 págs.

$2^{2}$ ed.

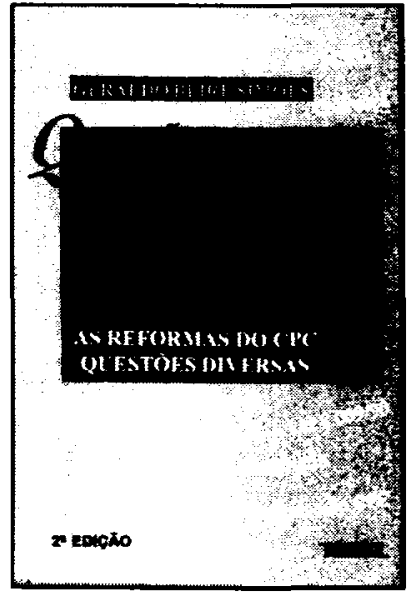

